\title{
Every Female Engineer is a Survivor - A Study of Defense Strategies in the Work of Female Engineers
}

\author{
Maely Barreto de Sousa ${ }^{1}$, Fatima Regina Ney Matos ${ }^{2, *}$ \\ ${ }^{1}$ University of Fortaleza (UNIFOR), Brazil \\ ${ }^{2}$ Superior Institute Miguel Torga (ISMT), Potiguar University, Brazil
}

Copyright $\mathrm{O} 2017$ by authors, all rights reserved. Authors agree that this article remains permanently open access under the terms of the Creative Commons Attribution License 4.0 International License

\begin{abstract}
The engineering work has peculiarities that still stand as barriers to women's role in the workspace. Like any type of work, it also generates suffering, resulting in individual defense strategies. The aim of this paper was to understand the defensive strategies applied by female engineers in the states of Bahia and Ceará against the suffering of work. The research is characterized as qualitative and data were treated with content analysis. As a result it was identified a new defense strategy category developed by female engineers, in addition to the ones pointed by the literature.
\end{abstract}

Keywords Defense Strategies, Female Engineers, Suffering at Work

\section{Introduction}

The differentiation of gender permeates the history of mankind and brings the principle of difference, as called by Agacinski [1]. This occurs through several different identities between men and women (biological, psychological, social identities), and they only reinforce this idea of differentiation between genres. This issue has been explained, therefore, through social and cultural constructions or using biological determinism in justification of the argument [7]. Therefore, a difference that "justifies" a hierarchy of men over women was instituted.

The Brazilian market had a rise in its graduated manpower in engineering in the 2000 s, also rising its wages, in relation to other professionals $[26 ; 31 ; 39]$. The combination of these two factors points to a hot market, but it still falls short of demand because of missing accredited professionals $[21 ; 25$; $33 ; 34]$. The different areas that engineering today offers should be taken into account and divided in traditional areas (civil, electrical, production, mechanical and chemical) and specific (oil, telecommunication, textile, fisheries and food), but even with these new options the civil engineering market is still the area forming more professionals [26].
Despite the market presenting itself as promising for engineering as a whole, as there was a small drop in unemployment from $4 \%$ to $2 \%$ of engineers between 2000 and 2010 [31], civil engineering is still presented as a male-dominated space over the last 17 years, despite the active participation of women in the segment [9]. Despite of this cenarium few studies were done female engineer, but no studies related to competitivity with male engineers in Brazil and their defences to keep on workplace.

Given this context, the aim of this study was to understand the defensive strategies applied by female engineers in the states of Bahia and Ceará, two states of northeast in Brazil. This area compared to other states still have a strong division on careers that should be chosen by men and women compared to the other areas of the country. Against the suffering of work, it was observed that the female engineers not only are in a predominantly male market, but they also deal with certain peculiarities of competitiveness with the other gender that makes up the historical preference of the professional profile of this area.

\section{Gender and Work}

The marginalization of women work force in market is a subject brought by some authors especially on the 70s. Marx [27] compared workforce of women and horses, but hiring the first were something simpler with a mathematical logic that do not deserve considerations. Saffiotti [38] says that a natural way was taken of women in the capitalistic way of production, there were no space for the entire workforce, and a criterion was defined for choosing workers. The careers offered to women had less prestige and lower salaries. The selection, used to be guided by work conditions, less than competences to run an activity [41]. From the $70 \mathrm{~s}$ intensification of inclusion of women in the labour market due to industrialization, urbanization and economic expansion was noticeable $[19 ; 36]$. The incorporation of female workforce becomes constant and growing without significant points that can be considered declines. In the 90's 
the occupation in both the formal and informal markets in Brazil, as well as in France and Japan is noticeable [22;8].

This expansion is based on historical events and social changes that allowed female participation in the job market, as the feminist movements of schooling expansion, reduction of number of children and outsourcing of some functions such as housemaid and babysitter $[19 ; 10]$. A new identity that "seeks recognition in the twenty-first century labor market" is developed [36]. Social roles are critical to understand even some preferences of men and women to careers related do Engineering [16]. Men have occupied leadership positions during history while women were directed to caretaker careers [17].

Woman seeks a balance between the time dedicated to work and the time available for family issues, beyond the personal ones. It is believed to be possible, and completely feasible and reasonable for the balance between professional and personal life to exist, despite the instability that the dynamics of today's world offers [42].

The idea of women as the weaker sex was something created and not necessarily arisen naturally. This was enhanced by the characteristics that differentiate the genders, as emotion being mostly attached to women, being it said in a general and empirically way. This concept is presented in an attempt to enhance a male superiority that has been redetermined over time, but not yet completed. It is defined by gender a socio-cultural construction and social representation, something that goes beyond simple physical distinction that lies on sex [7].

Simone de Beauvoir, gender reference in discussions, brings how the woman was conceived as the "other" in various social contexts throughout history. The denial of female identity as an "other", transformed females into a being without soul, without values, lifeless over the man and seen as an absolute subject. The author also stresses that for Aquinas the woman was an incomplete man, and despite the advance of history she has always been subordinate to man [6].

The hierarchy of ideas related to gender are legitimized by mythological, religious, philosophical and ideological foundations that create a reality that is not necessarily natural, but orders the relationships and experiences in society. Throughout human history, you can see the disappearance of women in records, making the development of humanity a story carried by men [7] and the conscious omission, if analyzed, left clues of active women.

In Brazil, despite of the rising economy on the $60 \mathrm{~s}$ and $70 \mathrm{~s}$, the career of engineer was not attractive on the $80 \mathrm{~s}$ and $90 \mathrm{~s}$. This made the country go through a gap of professionals that was felt years later [26]. On the 2000s the country could again feel the raising of the professionals on the market, as their salaries higher than the salaries of professionals in others areas of performance $[26,31,39]$.

The female engineers on this context still a small group comparing to men. This leads us to a scenario that is male predominant for 17 years [9]. According to the Brazilian census of 2010, men receive higher salaries than women. Baird and Williamson [3] affirm that the lack of woman in senior corporate roles continues to attract attention.

The gender difference exists, but the ranking and positioning power of one over the other is not something that is linked to human nature, but to a social institutionalization, created to regulate social relationships, and create a kind of order that is accepted as the best way of living in society, as an acceptable reductionism [23].

All social changes reflect in labour relations, and women's work is no different, "translating a way of organizing work that reflects a dimension of social segmentation" [35]. The need for rationalization of work [2] and control practices that maintain order in the activities rise as a component of these processes, populated by human labor, which allows the concreteness of the transformation of raw materials.

The almost imperceptible divide that separates the pleasurable work of one who brings suffering is translated in a way that is not necessarily logical. The activity that does not allow the escape of drive energy, tension that demands to be discharged [20;13], leads the individual to suffering in carrying out the activity. In this same logic is work, as at the same time it generates a kind of pleasure and wear (physical, psychological, or both) [32].

There is not, by the employee, a stranglehold on the activities carried out, before that it is seen as a productive resource, which receives a kind of "programming", is now molded, domesticated, forced to behave the way that the other wishes [12]. To Lancman and Uchida [24], Dejours contribution brings a different focus to the psychodynamic, where the normal state is not necessarily a healthy state. In the same way normality may reflect the healthy state, it may also indicate a condition, from the moment in which there is dispensed effort in an attempt to create a balance, which destabilises efforts against it, so that the individual can be kept active and accepted.

In this scenario, we can see the power that the organization has over the worker, and using the pretext to remain competitive the organization is able to mobilize the mass of employees towards a specific objective of the company. It is not taken into account if this movement generates the worker some kind of suffering, and the end is a scenario where employees suffer without position themselves against the situation, and accept the organizational purpose that justifies such a sacrifice [11]. They are, therefore, complicit in a kind of suffering they cause themselves, but the options do not allow many choices, because this behavior is systematic in organizations, leaving only to accept or to be excluded from that environment (to be dismissed from the organization).

The workers are explored in various aspects. Physically their body is explored through work, as it has to answer with the activity that it exerts in the way expected by the company. But their psychic functioning is operated by the organization of work, which covers the significant level of the individual. So the centralization appears in the subject, independent of their will, but shaped by the environment in which they 
operate. Their "behavioral style" is built along the experiences living and surviving in this environment. The will of the workers themselves does not direct their behavior, which is shaped by the very activities they carry out, taking this as regent of their speeches, behavior and conduct [15].

The dynamics of the studied work involves investments of practical intelligence, the individual's personality and cooperation, which are the elements that if well 'managed' are able to deal with the "madness" of the work and maintain health. Because of this, it is important for the psychodynamics of work the issue of mobilization and engagement required by the organization to the employee. The dependence of this level of involvement and requirement of the organizations to individuals occasionally make the subjectivity in tools that are exploited for productivity, performance and excellence, but end up causing suffering that can generate social pathologies such as violence, perversion and bondage [28].

The defense strategies can be defined as a set of rules related to conduct that are conducted and created by the people [15]. As they are related to the kind of work, they can take several forms "being marked by subtlety, ingenuity, diversity and invstivity" [28]. According to Dejours [13], defenses can be divided into three groups: protection, adaptation and exploitation strategies.

Defense strategies aimed at the protection are manifested by thinking, feeling and acting compensating for something. The situations of suffering become streamlined, alienating the employee of the generating causes of suffering. The employee does not act on the organization of work, but keeps the existing order unchanged. Over time this defense can lose its effect due to the increased casualization of the labor organization that intensifies the suffering, since no modification was developed.

The defenses considered adaptive and exploitative have the ability to run out in an even greater speed than the defenses of protection, because they demand a "physical and sociopsychic investment beyond their desire and ability" [28].

The defensive strategy on the one hand, presents itself as a solution to living with suffering that can also lead to alienation of the individual and hiding of the real causes of the problem. For the organization, the retention of alienation maintains the domain exercised over the worker, without question or changes in work organization. The experience of this paradox of organizations in making the maintenance of defenses and generate the suffering that it triggers, ends up making the safeguarding of employees' jobs, maintaining productive work and causes of suffering for employees unknown.

\section{Methodological Procedures}

For this work were chosen active women in the profession of engineering as subjects of research, not being taken into account the time in the market. The insertion was made for accessibility and the bond is considered.

The locus of this study occurred in the states of Bahia and Ceará, two states of northeast in Brazil, whit a strong culture of male and female activities compared to other areas of Brazil.

As collection method, semi-structured interviews were used, made by the researchers, with audio recording, as authorized by the interviewees.

The group researched total of 15 female engineers. For this study where considered as criteria some topics. All them were graduated on civil engineering, and all of them should be active in market and had working directly with civil engineering since the beginning of their careers, not having a chosen activity out of the civil engineering. By the time some of them were interviewed some had already worked whit different activities but all directly related to civil engineering. The difference of time in market, and areas of the civil engineering gave this study an expanded the perception female engineer. This number has not been pre-established because the purpose of the study was the saturation also known as redundancy [4].

For processing and analysis of data the technique of content analysis was chosen, as it is more suitable to the present paper form. In this work we proposed one category of analysis based on the literature, namely 'how to deal with work' where all the defense strategies are presented (table 1).

Table 1. Categories and Subcategories of Study Analysis

\begin{tabular}{|l|}
\hline Categories and Subcategories of Study Analysis \\
\hline $1-$ How to deal with work \\
\hline 1.1 Naturalization \\
\hline 1.2 Denial \\
\hline 1.3 Racionalization \\
\hline 1.4 Reactive Violence \\
\hline 1.5 Compensation \\
\hline 1.6 Distortion of Speech \\
\hline 1.7 Cleavage \\
\hline 1.8 Reframing \\
\hline
\end{tabular}

Source: Survey data, 2014

As an aid in the treatment of the data, the Atlas TI software was used generating the figure 1 . 


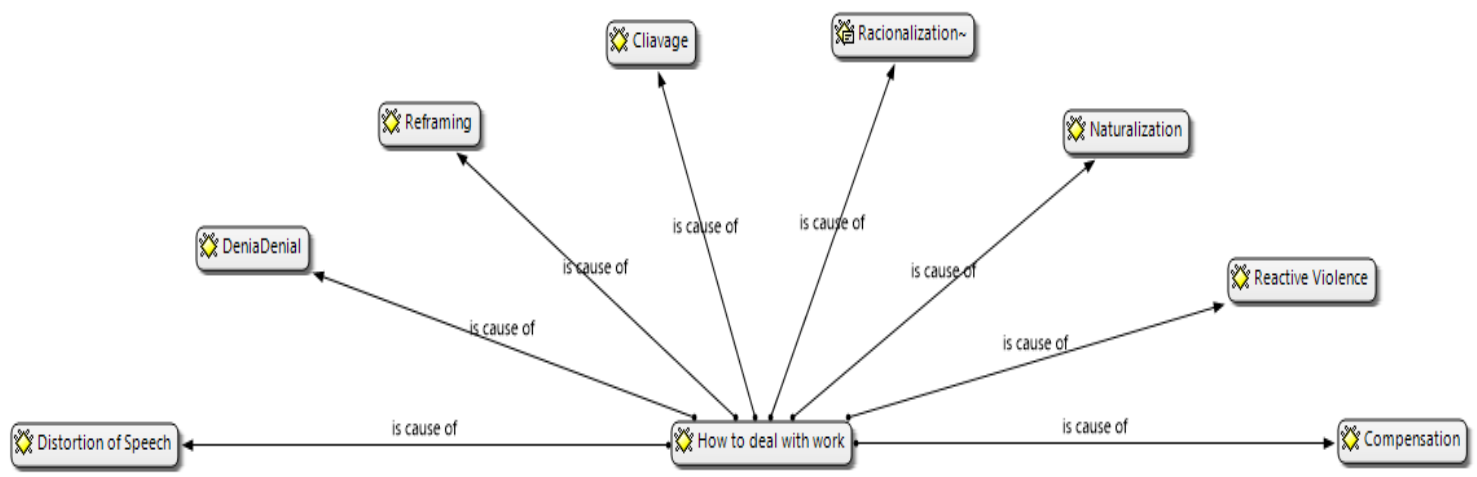

Figure 1. Map of analyzed data

\section{Discussion}

The first category refers to the defenses used by the female engineers to deal with the suffering of labor. Suffering is presented as something that is part of the workspace, as there is a deadlock between the female engineers and the organization, which exhaust the known possibilities to deal with the situation, combined with lack of possibility to change the task [14]. The constantly mentioned pressure and the course content in the interviews show how suffering of work is present and accepted.

The way in which they relate to the environment that constantly puts pressure denotes the fact that they are unable to imagine the workspace as a place that does not generate suffering. In this work this subcategory was called naturalization which appeared seven times. When dealing with data from this study that category, which had not been observed previously, was found and thus defined. It was identified that the female engineers get used to working structures that previously were strange to them.

The naturalization is presented not only as the custom with suffering of work generated by the pressure and unbalanced relationship between prescribed and real work, but it is also related to the fact that no longer were identified more discriminatory factors related to gender or impediments of performance and charges they related to the fact that they are women.

Denial is presented as a defense widely practiced in the engineering environment. In many instances, so that the work flow and interpersonal conflicts are circumvented, the female engineers have used denial as a way to euphemize unpleasant situations.

This mechanism, according to Dejours [12] is able to give rise to another problem: lie in organizations, which appears in the distortion subcategory of the speech and was present in this study when the female engineers said they had not had problems in their environment work, and later on in their interviews they told stories and experiences that showed otherwise.

Interestingly, the content of this interview is that the subject says that there is lack of differences between the professionals related to their gender, but then they immediately state that it does not happen 'mainly' in the office.

Rationalization was also presented several times in interviews with the female engineers. The content consists of conformity, socially acceptable justifications, as pointed out by Mendes and Abrahão [29], Mendes and Morrone [30], Ferreira and Mendes [18] and Barros and Mendes [5]. With this type of defense, the cited authors point to a passive behavior of the individual and a type of conformity to the existence of suffering. This subcategory showed the highest incidence in the interviews, being identified thirty times. One of the measures used by engineers is the justification of the existence of a hierarchy that needs to be present for the work to be done.

The shift between the coping and passivity are ways in which the rationalization may be presented $[29 ; 30 ; 18 ; 6]$. This way of defending the suffering brought a curious point in this study. Aware of the harsh environment in which engineering can be provided, some respondents said they deal with interpersonal issues emphasizing polishing and education in dealing with employees.

Even with the influences of other engineers and supervisors who treat work teams sharply, the female engineers make use of treatment pronouns such as "Mr.", and words like "please" and "thank you." This form of treatment to employees results, in their perception, in greater satisfaction in the workplace by the respect given by the female engineer to employees, and greater ease in meeting the goals and targets. Rationalization brings justifications for adopted behaviors. Also for this reason the female engineers consider themselves better in interpersonal relationships. They believe their dexterity is directly related to the fact that women are more empathetic to the problems of those around them.

Another way in which the rationalization is presented is in the fact that it is accepted that women are more docile and men are more cold and rude. This socially accepted justification makes the female engineer accept a rational explanation for the fact that there are differences between male and female engineers [29;30]. Another issue presented is hierarchies. All engineers who referred the hierarchy mentioned the importance to accomplish it. The hierarchy is 
presented here as a defense strategy, the rational explanation of the facts justifies its importance. But as the female engineers themselves said, few reported having had female heads, which directs to a masculine hierarchy [37; 40].

The way that can be considered by this work as one of the healthiest ways to deal with the suffering of the work is the redefinition. Applying this defense strategy the female engineers do not minimize or deny that there is suffering in their work, but come to see the situation from another angle, a worked-through angle $[15 ; 28]$.

The redefinition appeared more latent among the most experienced female engineers. Apparently, this kind of defense is acquired for applicability to the professional maturity. The female engineers who had this type of defense showed less fear in relation to the questioning of their professional capacity than the younger female engineers. The situations that generate the suffering of work are seen in a different way, so the defense strategy used is exactly to see problems from a different angle that does not generate so much suffering.

\section{Conclusions}

Being a female engineer is not presented as something easy. It required from the female professional a great deal of identity with the profession and resilience that makes her stay in business despite the suffering brought by work. The engineering environment is presented as a workspace that has yet to be conquered by female engineers. The professionals still feel the masculinization of space. So the female engineers end up creating defense strategies in an attempt to stay competitive, deal with the suffering of labor, and not give up careers as they witnessed some of their female classmates do.

Suffering at work is presented in a more latent form for younger female engineers who appear not to have been used to reality. Over the years of experience various defense strategies emerge as a way to maintain balance in workspaces, which is not necessarily synonymous with health. In this study a category that was called naturalization came out. In this defense strategy suffering is assumed and goes on to become customary for the female engineer.

The most common defense strategies found were rationalization and denial, followed by many others, such as naturalization and reframing. These strategies were not presented as a collective, despite the experiences being shared, but each one of the female engineers receive their suffering portion of the work and deals with it alone, without group support. Defense strategies exist only because of the duality of pleasure and pain that is presented at work, as they are an attempt of trying to balance the suffering with pleasure in work, seeking emotional and mental health [11].

But despite the work being presented in this way, the female engineers who keep working in the area identify with their activities. Please note that the perception of considering the limiting gender that hinder women's participation in the market was seen with two specific defense strategies, denial and rationalization.

The limitations of the participation of female engineers in the market in relation to gender trigger defense strategies as ways of dealing with the suffering of labor. The way in which the defenses are presented are the most diverse, and the contribution of this study was to identify a new category that allows a more clearly way to understand how defenses are established for the female engineers.

\section{REFERENCES}

[1] Agacinski, S. (1999). Política dos sexos. Oeiras: Celta Editora.

[2] Antunes, R. (2012). O caracol e sua concha: ensaios sobre a nova morfologia do trabalho. São Paulo: Boitempo Editorial.

[3] Baird, M., \& Williamson, S. (2011). Women, work and industrial relations in 2010. Journal of Industrial Relations, 53(3), 337-352.

[4] Bauer, M., \& Aarts, B. (2002). A construção do corpus: um princípio para a coleta de dados qualitativos. In Bauer, M.W. \& Gaskell, G. Pesquisa qualitativa com texto, imagem e som - Um manual prático (39-63). Petrópolis: Vozes.

[5] Barros, P. C. R., \& Mendes, A. M. B. (2003). Sofrimento psíquico e estratégias defensivas dos operários terceirizados da construção civil. Revista Psico- USF, 8 (1), 63-70.

[6] Beauvoir, S. (1949). O Segundo Sexo - Fatos e Mitos, 1. Tradução: S. Milliet, Rio de Janeiro: Nova Fronteira.

[7] Bravo, A. (2007). A invisibilidade do gênero feminino em Tintin - a conspiração do silêncio. Queluz: Chronos Editora.

[8] Bruschini, M. C. A.; Lombardi, M. R. A dupla face do trabalho feminino no Brasil: O empresgo domestico e as novas ocupações. Mulher e Trabalho (31-33). Porto Alegre, v. 1, n. 9, p. 31-33, 2000.

[9] Cardoso, A. F. C., Santos, J. V. P. dos, Nascimento, L. C. do, Paula, A. C. de, \& Figueiredo, V. C. de. (2014). Anais do Encontro da Associação Nacional de Pós-Graduação e Pesquisa em Administração, Rio de Janeiro, RJ, Brasil, 38.

[10] Carvalho Neto, A. M., Tanure, B., \& Andrade, J. (2010). Executivas: carreira, maternidade, amores e preconceitos. RAE - Eletrônica, 9 (1).

[11] Dejours, C. (2013). Uma nova visão do sofrimento humano nas organizações. In J. F. Chanlat. $O$ indivíduo na organização: dimensões esquecidas (Vol. 1, 3rd ed., 149-173). São Paulo: Atlas.

[12] Dejours, C. (2011). A loucura do trabalho: estudo de psicopatologia do trabalho (5th ed.) São Paulo: Cortez Editora.

[13] Dejours, C. (2004).Subjetividade, trabalho e ação. In: Revista produção, 4 (3), 27-34.

[14] Dejours, C. (1998). O Fator Humano. São Paulo: FGV. 
[15] Dejours, C., \& Abdoucheli, E. Intinerário teórico em psicopatologia do trabalho. In Dejours, C., Abdoucheli, E., \& Jayet, C. Psicodinâmica do trabalho: Contribuições da escolar dejouriana à análise da relação prazer, sofrimento e trabalho (1994). São Paulo: Atlas.

[16] Diekman, A.B., \& Eagly, A.H. (2008). Of men, women, and motivation: A role congruity account. In J.Y. Shah \& W.L. Gardner (Eds.), Handbook of motivation science (pp. 434 447). New York: Guilford

[17] Eagly, A.H., Wood, W., \& Diekman, A.B. (2000). Social role theory of sex differences and similarities: A current appraisal. In T. Eckes \& H.M. Trautner (Eds.), The developmental social psychology of gender (pp. 123-174). Mahwah, NJ: Erlbaum

[18] Ferreira, M. C., \& Mendes, A. M. (2003). Trabalho e riscos de adoecimento: o caso dos auditores fiscais da previdência social brasileira. Brasília: LPA/FENAFISP.

[19] Ferraz, S. F. de S.; Murupunga, A. N. de V.; Ferraz, S. B (2012). A inserção tardia de mulheres no mercado de trabalho. Anais do Encontro de Estudos Organizacionaisdo Encontro Nacional da Associação Nacional de Pós-Graduação e Pesquisa em Administração. Curitiba, PR, Brasil, 7.

[20] Freud, S. (1968). Além do príncipe do prazer. In Metapsicologia (1915).Paris: Gallimard.

[21] Gusso, D. A., \& Nascimento, P. A. M. M. (2011). Contexto e dimensionamento da formação de pessoal técnico-científico e de engenheiros. Radar: tecnologia, produção e comércio exterior, 12, 23-34.

[22] Hirata, H. (2011). Tendências Recentes da Precarização Social e do Trabalho: Brasil, França, Japão. Caderno $C R H$, 24 (spe 01), 13-20.

[23] Hirata, H., \& Kergoat, D. (2007). Novas Configurações da Divisão Sexual do Trabalho. Cadernos de Pesquisa, 37 (132), 595-609.

[24] Lancman, S, \& Uchida, S. (2003). Trabalho e subjetividade: o olhar da Psicodinâmica do Trabalho. Cadernos de Psicologia Social do Trabalho6, 79-90. Retrieved March 14, 2014, from http://www.revistasusp.sibi.usp.br/pdf/cpst/v6/v6a06.pdf.

[25] Maciente, A. N., \& Araújo, T. C. (2011). Requerimento técnico por engenheiros no Brasil até 2020. Radar: tecnologia, produção e comércio exterior, 12, 43-54.

[26] Maciente, A. N., \& Nascimento, P. A. M. M. A demanda por engenheiros e profissionais afins no mercado de trabalho formal. In M. Oliveira, P. A. M. M. Nascimento, A. N. Maciente, L. A. Caruso, E. M. Schneider(Ed.). Coletânea da rede de pesquisa Formação e mercado de trabalho, 4. (2014). Brasília: Ipea; ABDI.

[27] MARX, Karl. (1982). O Capital. Crítica da Economia Política - O Processo de Produção do Capital. Book 1, v. 1. São Paulo: DIFEL.

[28] Mendes, A. M. (2007). Da psicodinâmica à psicopatologia do trabalho. In A. M. MENDES. Psicodinâmica do Trabalho: teoria, método e pesquisa.São Paulo: Casa do Psicólogo.

[29] Mendes, A. M., \& Abrahão, J. I. (1996). A influência da organização do trabalho nas vivências de prazer e sofrimento dos trabalhadores: uma abordagem psicodinâmica. Psicologia Teoria e Pesquisa, 26 (2), 179-184.

[30] Mendes, A. M., \& Morrone, C. F. Vivências do prazer-sofrimento e saúde psíquica no trabalho: trajetória conceitual e empírica. In A. M. Mendes, Borges, L. O \& Ferreira, M. C. (2002). Trabalho em transição, saúde em risco. (25-42). Brasília: Universidade de Brasília.

[31] Menezes- Filho, N.(2012) Apagão de mão de obra qualificada? As profissões e o mercado de trabalho brasileiro entre 2000 e 2010. Retrieved August 3, 2014 from http://www.insper.edu.br/wp-content/uploads/2012/10/Apa g\%C3\%A3o-de-M\%C3\%A3o-de-Obra-Qualificada-Naerci o-Menezes-Filho.docx.pdf.

[32] Nogueira, C. M. A feminização no mundo do trabalho: entre a emancipação e a precarização. In Antunes, R. \& Silva, M. A. M.(2010). O Avesso do Trabalho (2a ed.,199-234). São Paulo: Expressão Popular.

[33] Pereira, R. H. M., \& Araújo, T. C. (2011). Oferta de engenheiros e profissionais afins no Brasil: resultados de projeções iniciais para 2020. Radar: tecnologia, produção e comércio exterior, 12, 35-42.

[34] Pompermayer, F. M., Nascimento, P. A. M. M., Maciente, A. N., Gusso, D. A., Pereira, \& R. H. M. (2011). Potenciais gargalos e prováveis caminhos de ajustes no mundo do trabalho no Brasil nos próximos anos. Radar: tecnologia, produção e comércio exterior, 12, 7-14.

[35] Rebelo, G. (2002). Trabalho e igualdade: mulheres, teletrabalho e trabalho a tempo parcial. Oeiras: Celta Editora.

[36] Rocha, J. B. da, Kubo, E K. de M., Nildes, R. P. L., Oliva, E. de C., \& Farina, M. C. (2013). Percepção de sucesso a carreira da mulher executiva brasileira. Anais do Encontro Nacional da Associação Nacional de Pós-Graduação e Pesquisa em Administração, Rio de Janeiro, RJ, Brasil, 37.

[37] Russo, G., \& Rassing, W. (2012). Multiple Glass Ceiling. Industrial Relations, 51 (4).

[38] Saffioti, H. (1967). A mulher na sociedade de classes: mito e realidade. 1967 . Petrópolis: Vozes.

[39] Salerno, M. S., Lins, L. M., Araujo, B. C. P. O. de, Gomes, L. A. V., \& Toledo, D.(2014).Uma proposta de sistematização do debate sobre falta de engenheiros no Brasil.In M. Oliveira, P. A. M. M. Nascimento, A. N. Maciente, L. A. Caruso, E. M. Schneider(Ed.). Coletânea da rede de pesquisa Formação e mercado de trabalho, 4. (2014). Brasília: Ipea; ABDI

[40] Stuart, P. (1992). What does the glass ceiling cost you? Personnel Journal, 71 (11), 70-80.

[41] Sullerot, Evelyne. (1970). A mulher no trabalho: História e Sociologia. Brazil: Ed. Espressão e Cultura, Tanure, B.; Carvalho Neto, A.; Andrade, J. O (2007). Executivos: Sucesso e Infelicidade. Rio de Janeiro: Campus/Elsevier. 